\section{Letter to the Editor RE: Singh AJ et al. Pediatr Res 67:619-623}

To the Editor: We read with great interest the article by Singh et al. (1) which provided a new idea on the effect of vitamin A in neonatal respiratory disease. Further clinical research may be needed, but some wonders exist which are as follows:

1. Three groups were set in the article: $\mathrm{I}=$ control; II $=$ surfactant; and III $=$ surfactant + vitamin A. Maybe groups II and III should be set, II = surfactant $(100 \%$ activity) and III = surfactant $(60 \%$ activity $)+$ vitamin $\mathrm{A}$, because the surface activity was $40 \%$ lower in group III than that in group II, and there was no significant difference of gas exchange between groups II and III. Did vitamin A have the efficacy equal to surfactant with $40 \%$ activity or what?

2. The study should have included both preterm and term infants. Although vitamin A supplementation could be more effective on premature infants with chronic lung disease (CLD), recent research suggested that $25 \%$ of infants remain vitamin A deficient despite vitamin A supplementation (2). The persistence of biochemical vitamin A deficiency might be due to impaired vitamin A transportation. Transthyretin, a major vitamin A transport protein, has been suggested to be reduced by inflammation (3).

3. Intramuscular administration of 5000 IU vitamin A every other day for 4 wk could decrease the incidence of CLD. How much and how often should vitamin A be supplemented to premature infants by intratracheal administration to ensure the effect?

4. How about vitamin A supplemented together with retinoic acid? Recent study has shown that a combination of vitamin A (the nutrient) and retinoic acid (the metabolite) improved more tissue retinoid stores than either vitamin A or retinoic acid alone in infant rats (4).

In conclusion, although intramuscular administration of vitamin A has been suggested to reduce the incidence of CLD, intratracheal administration of vitamin A may provide a new way with more absorb dosage and less pain.

Heqiang Sun

Team Three, Xueyuan Brigade Third Military Medical University Chongqing 400042, China

Yuan Shi Department of Pediatrics Third Military Medical University Chongqing 400042, China petshi530@vip.163.com

\section{REFERENCES}

1. Singh AJ, Bronshtein V, Khashu M, Lee K, Potts JE, Friel J, Chessex P 2010 Vitamin $\mathrm{A}$ is systemically bioavailable after intratracheal administration with surfactant in an animal model of newborn respiratory distress. Pediatr Res 67:619-623

2. Tyson JE, Wright LL, Oh W, Kennedy KA, Mele L, Ehrenkranz RA, Stoll BJ, Lemons JA, Stevenson DK, Bauer CR, Korones SB, Fanaroff AA 1999 Vitamin A supplementation for extremely-low-birth-weight infants. N Engl J Med 340:19621968

3. Ambalavanan N, Ross AC, Carlo WA 2005 Retinol-binding protein, transthyretin, and C-reactive protein in extremely low birth weight (ELBW) infants. J Perinatol 25:714-719

4. James ML, Ross AC, Bulger A, Philips JB 3rd, Ambalavanan N 2010 Vitamin A and retinoic acid act synergistically to increase lung retinyl esters during normoxia and reduce hyperoxic lung injury in newborn mice. Pediatr Res 67:591-597

\section{Letter to the Editor RE: Okogbule-Wonodi et al. Pediatr Res 69:442-447}

To the Editor: We read with great interest the recent article by Okogbule-Wonodi et al. (1) about whether Ureaplasma respiratory tract colonization of preterm infants $<33$ wk gestation is associated with an increased risk for necrotizing enterocolitis (NEC). The authors evaluated 368 infants $<33$ wk gestation with one or more tracheal or nasopharyngeal aspirates for Ureaplasma culture and PCR obtained during the first week of life. They stated that NEC was confirmed in 29 of $368(7.9 \%)$ of the combined cohorts, and the incidence of NEC was 2.2-fold higher in Ureaplasma-positive (12.3\%) than Ureaplasma-negative $(5.5 \%)$ infants $<33 \mathrm{wk}$ and 3.3-fold higher in Ureaplasmapositive (14.6\%) than Ureaplasma-negative (4.4\%) infants $\leq 28$ wk. In addition, cord serum IL- 6 and IL- $1 \beta$ concentrations were significantly higher in Ureaplasma-positive than in Ureaplasmanegative NEC-affected infants, and so, the authors suggested that Ureaplasma may be a factor in NEC pathogenesis in preterm infants by contributing to intestinal mucosal injury and/or altering systemic or local immune responses.

We have recently completed a study concerning effects of Ureaplasma respiratory tract colonization and its management on development of chronic lung disease (unpublished data). When we evaluated 224 enrolled infants who were $<32$ wk and seeked for Ureaplasma respiratory colonization with one or more tracheal or nasopharyngeal aspirates for Ureaplasma culture, we could not demonstrate any relationship between Ureaplasma colonization and NEC development (Table 1), which is similar to previous published study by Perzigian et al. (2). Two important factors, which were associated with NEC stage $\geq 2$ development, were late-onset proven sepsis, volume of red blood cell transfusion, and cord serum IL-6 (Table 1). Multivariate logistic regression analysis revealed that there was only significant association between the red blood cell transfusion and NEC development (OR, 1.4; 95\% CI, 1.18-1.74; $p=0.01$ ). Although our results shows similarity with study by Okogbule-Wonodi et al. (1) in high cord serum IL-6 levels and we agree with authors on its possible association with NEC development, it is obvious that 
Table 1. The relation of clinical variables with necrotizing enterocolitis development

\begin{tabular}{|c|c|c|c|}
\hline & $\begin{array}{r}\text { No NEC } \\
(n: 193)\end{array}$ & $\begin{array}{l}\text { NEC } \\
(n: 31)\end{array}$ & $p$ \\
\hline Birth weight, mean $\pm \mathrm{SD}(\mathrm{g})$ & $1009 \pm 158$ & $997 \pm 178$ & 0.68 \\
\hline $\mathrm{GA}$, mean $\pm \mathrm{SD}(\mathrm{wk})$ & $27.9 \pm 1.7$ & $27.3 \pm 1.9$ & 0.10 \\
\hline Male, $n(\%)$ & $84(43.5)$ & $11(35.5)$ & 0.40 \\
\hline Cesarean delivery, $n(\%)$ & $143(74.1)$ & $24(77.4)$ & 0.69 \\
\hline Prenatal steroids, $n(\%)$ & $135(69.9)$ & $23(74.2)$ & 0.63 \\
\hline $\begin{array}{l}\text { Premature rupture of membrane } \\
\quad>18 \mathrm{~h}, n(\%)\end{array}$ & $29(15)$ & $8(25)$ & 0.13 \\
\hline $\begin{array}{l}\text { Respiratory distress syndrome, } \\
n(\%)\end{array}$ & $120(62.2)$ & $21(67.7)$ & 0.55 \\
\hline Caffeine treatment, $n(\%)$ & $154(79.8)$ & $27(87.1)$ & 0.33 \\
\hline Diuretic treatment, $n(\%)$ & $13(7)$ & $4(14.1)$ & 0.13 \\
\hline $\begin{array}{l}\text { Duration of mechanical ventilator, } \\
\text { mean } \pm \mathrm{SD}(\mathrm{d})\end{array}$ & $2.3 \pm 4.7$ & $3.7 \pm 5.4$ & 0.15 \\
\hline Duration n-CPAP, mean \pm SD (d) & $4.1 \pm 4.6$ & $3.5 \pm 2.3$ & 0.49 \\
\hline $\begin{array}{l}\text { Total days on supplemental oxygen, } \\
\text { mean } \pm \text { SD (d) }\end{array}$ & $16.7 \pm 25.1$ & $13.7 \pm 22.1$ & 0.55 \\
\hline $\begin{array}{l}\text { Transfusion of red blood cells } \\
\text { volume } \pm \mathrm{SD}(\mathrm{mL})\end{array}$ & $50.8 \pm 32.3$ & $85 \pm 45.9$ & $<0.01$ \\
\hline $\begin{array}{l}\text { Late-onset sepsis (proven sepsis), } \\
\quad n(\%)\end{array}$ & $73(37.8)$ & $19(61.3)$ & 0.01 \\
\hline Patent ductus arteriosus, $n(\%)$ & $66(34.2)$ & $14(45.2)$ & 0.23 \\
\hline $\begin{array}{l}\text { Ureaplasma urealyticum } \\
\quad \text { colonization, } n(\%)\end{array}$ & $67(34.7)$ & $10(32.3)$ & 0.78 \\
\hline $\begin{array}{l}\text { Cord serum Interleukin-6 (pg/mL), } \\
\text { mean } \pm \mathrm{SD}\end{array}$ & $64.9 \pm 159$ & $233.5 \pm 352$ & $<0.01$ \\
\hline $\begin{array}{l}\text { Cord serum C-reactive protein } \\
(\mathrm{mg} / \mathrm{mL}), \text { mean } \pm \mathrm{SD}\end{array}$ & $1.9 \pm 5.8$ & $0.9 \pm 0.8$ & 0.28 \\
\hline $\begin{array}{l}\text { Cord serum white blood cell count } \\
\times 10^{3} \text {, mean } \pm \mathrm{SD}\end{array}$ & $17 \pm 34$ & $13.5 \pm 7$ & 0.58 \\
\hline $\begin{array}{l}\text { Cord serum platelets } \times 10^{6} \\
\text { mean } \pm \mathrm{SD}\end{array}$ & $224 \pm 77$ & $210 \pm 89$ & 0.37 \\
\hline Mortality, $n(\%)$ & $10(5.2)$ & 9 (29) & $<0.01$ \\
\hline
\end{tabular}

authors did not investigate the relationship between red cell transfusion and NEC development. We know that in addition to our results, some recent trials demonstrated the impressive association between transfusion and NEC development $(3,4)$, and we suggest that Okogbule-Wonodi et al. (1) should reevaluate their patients from this point.

\section{Ramazan Ozdemir Omer Erdeve Sadık Yurttutan Ugur Dilmen} Division of Neonatology Zekai Tahir Burak Maternity Teaching Hospital Ankara, Turkey ramazanoz@yahoo.com.tr

\section{REFERENCES}

1. Okogbule-Wonodi AC, Gross GW, Sun CC, Agthe AG, Xiao L, Waites KB, Marie Viscardi R 2011 Necrotizing enterocolitis is associated with Ureaplasma colonization in preterm infants. Pediatr Res 69:442-447

2. Perzigian RW, Adams JT, Weiner GM, Dipietro MA, Blythe LK, Pierson CL, Faix RG 1998 Ureaplasma urealyticum and chronic lung disease in very low birth weight infants during the exogenous surfactant era. Pediatr Infect Dis J 17:620-625

3. Paul DA, Mackley A, Novitsky A, Zhao Y, Brooks A, Locke RG 2011 Increased odds of necrotizing enterocolitis after transfusion of red blood cells in premature infants. Pediatrics 127:635-641

4. Blau J, Calo JM, Dozor D, Sutton M, Alpan G, La Gamma EF 2011 Transfusionrelated acute gut injury: necrotizing enterocolitis in very low birth weight neonates after packed red blood cell transfusion. J Pediatr 158:403-409
Response: We thank Ozdemir et al. for their comments and suggestions pertaining to our recent article entitled "Necrotizing enterocolitis is associated with Ureaplasma colonization in preterm infants." The authors note that they have unpublished data based upon the evaluation of 224 infants $<34$ wk gestation for Ureaplasma colonization by one or more tracheal or nasopharyngeal aspirate cultures. The authors did not find a significant association between Ureaplasma colonization and the development of necrotizing enterocolitis (NEC) in their cohort but other factors such as red blood cell transfusions $(85 \pm 45.9$ versus $50.8 \pm 32.3 ; p<0.01)$ and proven late-onset sepsis $(61.3 \%$ versus $37.8 \% ; p=0.01$ ) were significant. Similar to our findings, cord serum IL-6 levels were higher in Ureaplasma-colonized NEC infants. Ozdemir et al. further stated that after multivariate analysis, only the number of red blood cell transfusions received remained significantly associated with the development of NEC (OR, 1.4; 95\% CI, 1.18-1.74; $p=0.01$ ).

The pathogenesis of NEC remains poorly understood. Although prematurity is the greatest risk factor for developing NEC, epidemiological studies suggest a multifactorial etiology $(1,2)$. Intestinal immaturity heralded by abnormal microbial intestinal colonization, alterations in intestinal blood flow, and a highly immunoreactive intestinal mucosa are important predisposing factors to the extensive mucosal damage seen in NEC. Contrary to our findings, Ozdemir et al. did not find an association between Ureaplasma colonization and NEC stage $\geq 2$ in their cohort. Several factors may explain the differences in these findings. Our sample size was larger than both the authors' and the Perzigian cohorts (3). We analyzed data from 368 subjects, and NEC incidence remained greater in Ureaplasma colonized compared with negative infants even when substratified to only include infants $\leq 28$ wk gestation at birth. Because culture methodology details were not provided by Ozdemir et al., we cannot comment on whether differences in Ureaplasma detection may have contributed to differences in study outcomes. Although the majority of subjects in our sample were of African-American descent, it is not clear whether the authors included race in their descriptive variables. The incidence of NEC is known to be higher in the African-American population in the United States which is attributed to the higher rate of preterm delivery in African-Americans (4).

Several retrospective studies including the one by the authors have shown a possible association between the timing of packed red blood cell transfusions and the subsequent development of NEC (5). Other recent reports do not define a clear relationship (6). It is therefore difficult to conclusively state causality. Transfusion of the anemic preterm infant has been suggested to cause a reperfusion-type injury to an already compromised immature intestinal mucosa (7). Ingestion of Ureaplasmainfected amniotic fluid by the fetus could potentially initiate an excessive systemic and local intestinal inflammatory response and thus predispose these very LBW infants to NEC. Anemia-related tissue hypoxia may also play a role (8). Although we appreciate the comments of Ozdemir et al., the results from our predominantly African-American sample indicates that a reevaluation of our data along their suggested lines would be of no additional value to our study. 